\title{
Changes in soil temperature and water content under mobile soil steam disinfection
}

\author{
Zhenjie Yang ${ }^{1,2}$, Xiaochan Wang ${ }^{1 *}$, Muhammad Ameen ${ }^{1}$ \\ (1. College of Engineering, Nanjing Agricultural University, Nanjing 210031, China; \\ 2. College of Mechanical and Electrical Engineering, Yunnan Agricultural University, Kunming 650201, China)
}

\begin{abstract}
The soil steam injection method is one of the most effective disinfection methods, and the determination of the steam pipe structure parameters is very important. The steam capillary diameter (SCD) affects the steam flow field in each pipe, which in turn affects the steam changes in the soil flow range and soil temperature (ST). Larger SCD would make lower ST in clay loam, silt loam, and sandy clay loam. The effectiveness of an SCD of $10 \mathrm{~mm}$ was verified by a mobile disinfection test at walking speeds of $10 \mathrm{~cm} / \mathrm{min}$ and $30 \mathrm{~cm} / \mathrm{min}$ under soil water content (SWC) of $15 \%$ and 35\%, respectively. The results showed that when the walking speed was $10 \mathrm{~cm} / \mathrm{min}$, the initial SWC was proportional to the ST. However, when the walking speed was $30 \mathrm{~cm} / \mathrm{min}$, the law was exactly the opposite; that is, the initial water content is inversely proportional to the ST. The research can provide a theoretical research foundation for increasing soil temperature for efficient soil steam disinfection.
\end{abstract}

Keywords: soil steam disinfection, steam capillary diameter, steam capillary vent, soil temperature, soil water content DOI: $10.25165 / j . i j a b e .20211403 .5026$

Citation: Yang Z J, Wang X C, Ameen M. Changes in soil temperature and water content under mobile soil steam disinfection. Int J Agric \& Biol Eng, 2021; 14(3): 140-147.

\section{Introduction}

The problem of continuous cropping obstacles in China is becoming more and more serious. Most of the problems of continuous cropping are caused by harmful bacteria in the soil. Among the chemical methods for controlling these bacteria, methyl bromide fumigation is the most widely used due to its low cost and high effectiveness, but chemical methods pollute the soil and crops, ultimately endangering human health ${ }^{[1-5]}$. Experts from various countries have done a lot of research on soil physical disinfection methods. The flame disinfection method can generate a high temperature of $1000^{\circ} \mathrm{C}$ in a short time. The high temperature of the flame is directly sprayed to the ground for disinfection, which avoids the loss of heat during transmission, but it cannot completely kill harmful bacteria in deep soil. At the same time, the high temperature will remove the effective water in the soil and change the physical properties of the soil. The flame disinfection method can achieve a good disinfection effect in sandy soil, but it is not applicable to heavy red soil, clay soil, and silt soil. The solar energy disinfection method applies to areas with abundant heat resources. This method is highly operable and low in cost, but it is restricted by external factors such as weather and season. In the high-temperature hot water method, because the heat capacity of water is greater than steam, the soil can continue to be in a high temperature state when this technology is applied, but the water consumption per operation is large, and its use is limited in areas with insufficient water resources. The electric disinfection

Received date: 2020-04-08 Accepted date: 2021-02-26

Biographies: Zhenjie Yang, $\mathrm{PhD}$, Teaching Assistant, research interest: injection soil steam disinfection, Email: yangzj@ynau.edu.cn; Muhammad Ameen, PhD, research interest: agricultural engineering, Email: 2016212014@ njau.edu.cn.

*Corresponding author: Xiaochan Wang, $\mathrm{PhD}$, Professor, research interest: modeling, biological systems and environment. Department of Electrical Engineering, College of Engineering, Nanjing Agricultural University, Box 96, No.40 Dianjiangtai Road, Pukou District, Nanjing 210031, Jiangsu, China. Tel: +86-25-58606567, Email: wangxiaochan@njau.edu.cn. method and microwave disinfection method have the problems of high operation cost and complicated operation when disinfecting soil. Compared with other disinfection methods, the soil steam disinfection method is currently an ideal thermal disinfection treatment method. This method can not only effectively kill harmful fungi, bacteria, viruses and pests, etc., but high temperature steam can also humidify the soil to change the aggregate structure and restore the pellets, moreover, this method has the advantages of high efficiency, cleanliness, no pollution, and seeding within a short time after disinfection.

Starting in 2015, with the global ban on methyl bromide, experts have restudied soil steam disinfection methods ${ }^{[6-10]}$. The soil steam disinfection method is a type of physical disinfection method in which high-temperature steam is transported to the soil, and harmful bacteria are killed by the principle of high-temperature disinfection ${ }^{[10-16]}$. The soil steam disinfection methods include the Hoddesdon method, sheet steaming method, and injection method.

In the Hoddesdon method, perforated steam steel pipes are buried in $30 \mathrm{~cm}$ deep soil and connected to a steam generator. After the steam disinfection, the steam pipes are pulled out of the soil and reused in the next zone ${ }^{[17]}$. In sheet steaming, the soil is covered with a thermal insulation film sealed at the edges, and vapor is pumped under the thermo-resistant sheet. Using sheet disinfection, deep disinfection is difficult because a large amount of steam is concentrated on the surface of the soil, and there will also be superheating of the surface soil. In the steam injection method, steam is injected into the soil and diffuses up to the soil surface. During this process, the steam condenses continuously, and the liquid water evaporates continuously, forming a unique evaporation-condensation mechanism ${ }^{[6]}$ that is beneficial to the diffusion of steam and has the advantage of rapidly increasing the soil temperature (ST). Gay et al. ${ }^{[6]}$ carried out a static steam disinfection test that used a $2 \mathrm{~m} \times 2.5 \mathrm{~m}$ iron hood with 99 injectors, which were $250 \mathrm{~mm}$ long and $21 \mathrm{~mm}$ in diameter. It was found that with a soil steam pressure of $50 \mathrm{kPa}$, the soil steam injection pipe could disinfect $16 \mathrm{~cm}$ deep soil within $6 \mathrm{~min}$, effectively killing harmful microorganisms. 
In the process of applying the above methods, experts found that the efficacy of steam disinfection also depends on the physical nature of the soil and its humidity. Gay et al. ${ }^{[6]}$ and Philip et al. ${ }^{[18]}$ found that in the static disinfection method, the initial soil water content is proportional to the final ST, that is, when the soil moisture content is high, the ST after disinfection is also high, because steam does not easily diffuse in the sand, meaning that the ST does not significantly increase. On the other hand, the clay soil has more clay and silt than sand, so its ability to hold water is higher and thus it exhibits an improved heat storage capacity.

For mobile disinfection, Peruzzi developed a self-propelled machine with a walking speed of $150 \mathrm{~m} / \mathrm{h}$. With a vapor pressure of $0.8 \mathrm{MPa}^{[7]}$, Peruzzi used one or two cone steam holes to perform the test and found that two cone holes could disinfect soil at different depths. The use of $\mathrm{CaO}$ at the highest application rate, together with the adoption of soil mulching with a plastic film, gave the best results in terms of the ST value and soil heat persistence. Raffaelli and Lars ${ }^{[14]}$ studied a band-steaming end-effector and used a vapor pressure of $1.18 \mathrm{MPa}$ at speeds of $200-500 \mathrm{~m} / \mathrm{h}$.

The above studies show that soil water content is evaluated with mainly static methods, and for the mobile disinfection with different walking speeds, the effects of the initial water content of the soil on the ST may be different due to the short time that the steam pipe remains in the soil. In addition to the soil, walking speed, the water content acting on the ST and the disinfection end-effector, such as the steam pipe diameter and vent size, will also affect the $\mathrm{ST}^{[19-22]}$. Structural changes cause changes in the flow field inside the pipe and thus affect the diffusion of steam in the soil. For example, in a study on soil vapor extraction (SVE), $\mathrm{Li}$ et al. ${ }^{[23]}$ tested the effect of the steam velocity on the decontamination. It was found that increasing the flow rate would accelerate the evaporation of hydrocarbon contaminants in the soil, that is, increasing the aeration rate increases the temperature. The diffusion range of gas in the soil expands the high-temperature range of the soil and thus accelerates the volatilization of hydrocarbon pollutants in the soil.

In summary, the determination of the steam pipe parameters is very important, but few studies have investigated the relationship between the steam capillary diameter (SCD) and ST. Therefore, we need to study the effect of the capillary pipe diameter on the ST and water content in clay loam, silty loam, and sandy clay loam. The effectiveness of these combinations was verified by mobile disinfection tests at walking speeds of $10 \mathrm{~cm} / \mathrm{min}$ and $30 \mathrm{~cm} / \mathrm{min}$ under SWC of $15 \%$ and $35 \%$. Experiments were conducted to study the influences of the SCD on the ST of clay loam, silt loam, and sandy clay loam, as well as the associated intrinsic relationships, and study the effect of the interactions between the walking speed and soil initial water content on the ST, which provide a theoretical basis for improving the ST in the future.

\section{Materials and methods}

\subsection{Test materials}

The steam disinfection pipe is a custom-made hollow iron pipe with a wall thickness of $1 \mathrm{~mm}$. The single capillary has a length of $350 \mathrm{~mm}$, with one end open and the other end closed. Since this study used a mobile soil steam sterilizer, to ensure the rapid diffusion of steam during the disinfection and uniform distribution to each layer of the soil, each capillary has 9 holes $(3 \times 3)$. The holes correspond to depths of $0-5 \mathrm{~cm}, 5-15 \mathrm{~cm}$, and $15-20 \mathrm{~cm}$ in the soil. The specific parameters are shown in Figure 1.

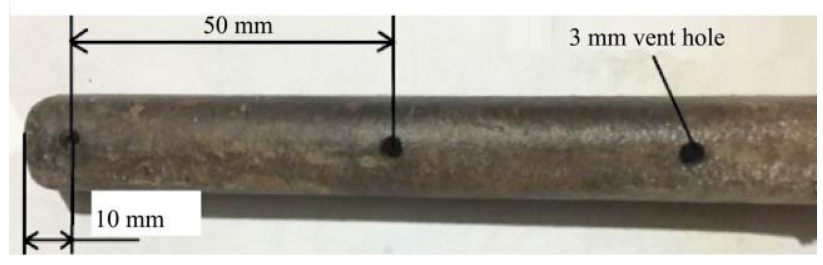

Figure 1 Steam pipe parameters

The basic properties of the tested soils are shown in Table 1 . After the uniform rotation of the tested soil, the initial ST is $(22 \pm 1.2)^{\circ} \mathrm{C}$ and the initial soil water content is $(24 \pm 2) \%$. All of the tested soil was naturally dried and was passed through a $2 \mathrm{~mm}$ sieve.

Table 1 Physical properties of soil

\begin{tabular}{ccccc}
\hline \multirow{2}{*}{ Soil types } & $\begin{array}{c}\text { Bulk } \\
\text { density } \\
\text { /g. } \mathrm{cm}^{-3}\end{array}$ & $\begin{array}{c}\text { Clay } \\
(<0.002 \mathrm{~mm})\end{array}$ & $\begin{array}{c}\text { Silt } \\
(\geq 0.002-0.02 \mathrm{~mm})\end{array}$ & $\begin{array}{c}\text { Sand } \\
(\geq 0.02-2 \mathrm{~mm})\end{array}$ \\
\hline Clay loam & 1.15 & 53.3 & 23.3 & 23.3 \\
Silty loam & 1.15 & 11.0 & 71.6 & 17.4 \\
Sandy clay loam & 1.20 & 20.0 & 0.3 & 79.7 \\
\hline
\end{tabular}

\subsection{Test equipment}

As shown in Figure 2, the test equipment is equipped with a DE-WEINI steam conveying pipe 1 (Shanghai Jiyou Pipe Co., Ltd.), the homemade steam capillary 2, a lifting device 3, an H100 inverter 4 (Jiangsu Oumu Electric Co., Ltd.), a YVP 90L-2 variable frequency speed regulation three-phase asynchronous motor 5 (Shanghai Jiesu Special Motor Factory), a WPA Reducer 6 (Hangzhou Genfang Transmission Machinery Co., Ltd.), a soil trough $7(300 \mathrm{~cm} \times 140 \mathrm{~cm} \times 40 \mathrm{~cm})$, an LSS0.1-0.7-Y steam generator 8 (Jiangsu Yueheng Special Equipment Manufacturing Co., Ltd.), an LYK-10 steam adjustable pressure switch (Changzhou Liping Electronic Equipment Co., Ltd.), a Y60 pressure gauge (Fuyang Hongsheng Instrument Factory), and a WSS-413 thermometer (Jiamin Instrument Co., Ltd.).

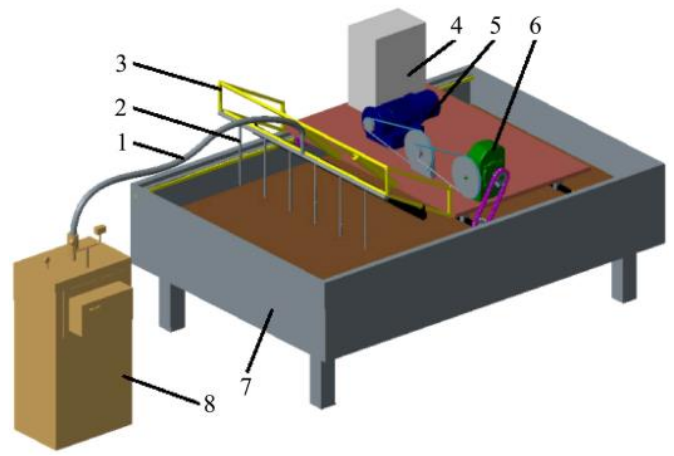

1. Steam conveying pipe 2. Steam capillary 3. Lifting device 4. Inverter 5. Frequency conversion three-phase asynchronous motor 6. Reducer 7. Soil trough 8. Steam generator

Figure 2 Steam disinfection test equipment

When the sterilizer is in operation, the regulating frequency converter 4 can adjust the rotation speed of motor 5 to change the running speed of the machine; that is, the traveling wheel of the sterilizer can advance at a constant speed along a fixed parallel rail laid above the soil groove 7. During the mobile disinfection process, the adjustment of lifting device 3 can control the insertion depth of the steam capillary 2. When the sterilizer is operated smoothly, different steam temperatures are obtained by adjusting the pressure of the boiler 8 . Then, the high-temperature steam is transported through the steam transport hose 1 to the end disinfection mechanism (steam capillary) for the soil steam 
disinfection.

\subsection{Test design and procedure}

For each combination of SCD, soil type, walking speed, and SWC level, three repetitions were performed, for a total of 51 trials, as shown in the test design in Table 2.

Table 2 Experimental design of soil steam disinfection

\begin{tabular}{cccc}
\hline SCD/mm & Soil type & $\begin{array}{c}\text { Walking speed } \\
\text { /cm } \cdot \mathrm{min}^{-1}\end{array}$ & $\begin{array}{c}\text { Initial } \\
\text { SWC/\% }\end{array}$ \\
\hline $10,15,20$ & clay loam, silty loam, sandy clay loam & 20 & 25 \\
10 & clay loam, sandy clay loam & 10,30 & 15,35
\end{tabular}

Note: SCD is steam capillary diameter; SWC is soil water content, the same as below.

The ST and water content test system, including NTC-B3950 soil temperature sensors (Jinan Zhengmiao Automation Equipment Co., Ltd.), ZMSF-AB soil water content sensors (Jinan Zhengmiao Automation Equipment Co., Ltd.), an SR20 PLC (Siemens), and a TPC7062 screen (Kunlun state), is shown in Figure 3. The temperature and water content sensors before calibration are calibrated for normal use.

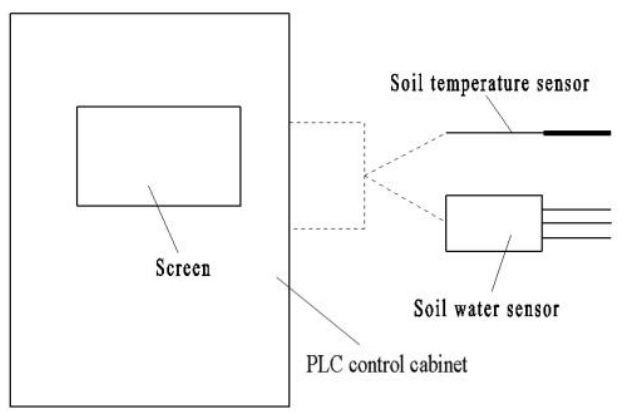

Figure 3 Soil temperature-water content test system diagram

The pressure of the vapor generator and the ball valve switch were adjusted to set the vapor to a pressure of $0.3 \mathrm{MPa}$ and a temperature of $130^{\circ} \mathrm{C}$ to perform the soil steam disinfection tests. Since the steam capillary is symmetrically distributed for the main pipe, the ST is measured only in the right half. First, the steam pipe was vertically inserted into the uniformly plowed soil so that the bottom end of the steam pipe was $20 \mathrm{~cm}$ from the soil surface. Then, the sensors were buried horizontally at 0, 90, 180, 270, and $360 \mathrm{~cm}$ regarding L1 steam capillary as the initial position and vertically at $0,5,10,15$, and $20 \mathrm{~cm}$ from the surface of the soil. The test points are $5 \times 5=25$, and the distance between points $A$ and B is $20 \mathrm{~cm}$, as shown in Figure 4. Start the motor and adjust the inverter motor to ensure that the steam disinfection capillary moves smoothly from point A to point B at a constant speed. The soil conditions are measured at 25 test points before the capillary reaches point $\mathrm{B}$ through the $\mathrm{ST}$ and water content test system.

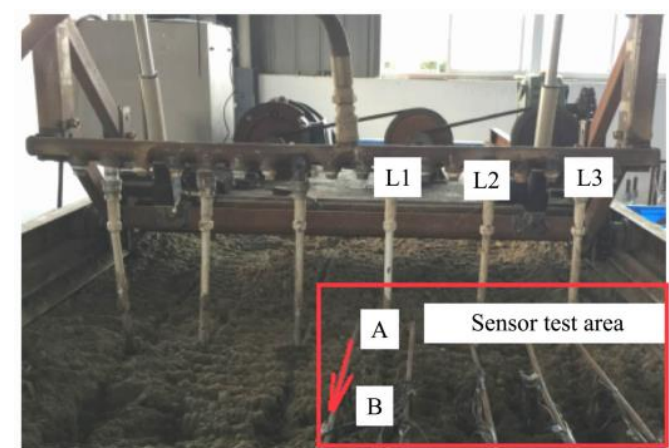

Note: Point A represents the initial position of the test, point B represents the end position of the test.

Figure 4 Soil steam disinfection test

\subsection{Steam flow field simulation}

According to the literature ${ }^{[19-22]}$, the steam capillary diameter and the vent hole diameter may affect the flow velocity in the pipe, thus affecting the diffusion range of the steam in the soil. Therefore, a flow field simulation of 3 SCDs $(10,15,20)$ and 3 vent hole diameters VHDs $(3 \mathrm{~mm}, 5 \mathrm{~mm}$, and $7 \mathrm{~mm})$ was performed.

\subsubsection{Steam capillary model and meshing}

The steam mains, branch pipes and capillaries are key components of the end-effector mechanism. The steam main pipe (20 mm diameter) is connected to the steam conveying pipe. According to the width of the sterilizer, $1200 \mathrm{~mm}$, the steam branch pipe (20 mm diameter) is designed to be $1200 \mathrm{~mm}$ long, and 6 steam capillaries are evenly arranged on the steam branch pipe. The distance between the capillaries is $180 \mathrm{~mm}$ (Figure 5a). In this study, the steam pipe model is meshed by an unstructured tetrahedral mesh, and the number of grid cells is approximately 330000 . Among them, the pipeline vent and local position are meshed and encrypted, as shown in Figure 5b.

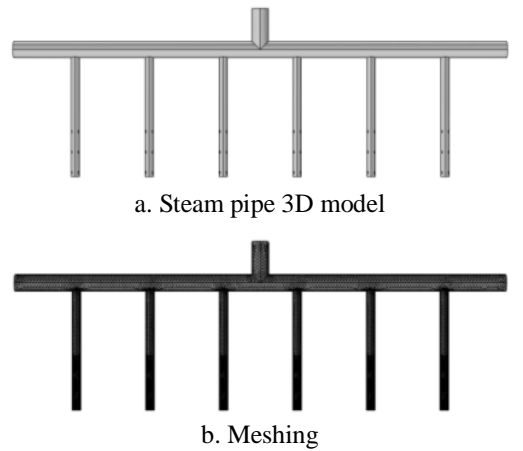

Figure 5 Steam pipe 3D model and meshing

\subsubsection{Simulation methods and settings}

When the average velocity of the steam in the pipe is above $5 \mathrm{~m} / \mathrm{s}$, the Reynolds number Re is greater than the critical value of the turbulent flow ${ }^{[19-22]}$, so the motion of the whole process is turbulent. The flow field in the pipe was numerically simulated using COMSOL Multiphysics 5.3a software. The simulation process was performed using the Standard k-turbulence model, and the SIMPLE algorithm was used to solve the model. The residual convergence criterion was $10^{-4}$. The steam main inlet is selected as the flow inlet boundary condition, and the VHD is set to the static pressure outlet boundary condition with a static pressure of 0 . The pipe wall surface adopts a no-slip boundary condition, the inlet and outlet and the wall surface is at an ambient temperature of $22^{\circ} \mathrm{C}$, and the steam parameters are as shown in Table 3 .

Table 3 Steam physical parameters for disinfection test

\begin{tabular}{ccccc}
\hline $\begin{array}{c}\text { Vapor pressure } p \\
/ \mathrm{MPa}\end{array}$ & $\begin{array}{c}\text { Temperature } t \\
/{ }^{\circ} \mathrm{C}\end{array}$ & $\begin{array}{c}\text { Density } \rho \\
/ \mathrm{kg} \cdot \mathrm{m}^{-3}\end{array}$ & $\begin{array}{c}\text { Dynamic } \\
\text { viscosity } \mu \\
/ \mathrm{Pa} \cdot \mathrm{s}\end{array}$ & $\begin{array}{c}\text { Thermal } \\
\text { conductivity } \lambda \\
/ \mathrm{W} \cdot \mathrm{m}^{-1} \cdot \mathrm{K}^{-1}\end{array}$ \\
\hline 0.3 & 130 & 1.497 & $1.3 \times 10^{-5}$ & $2.76 \times 10^{-2}$ \\
\hline
\end{tabular}

\subsection{Data analysis}

The different ST data were input into SPSS 22 statistical software, which can provide a factor analysis of the temperature. After the test, input the soil temperature and moisture data collected by the sensor into the surfer software, and surfer software was used to produce the ST and water content profiles.

\section{Results and discussion}

\subsection{Simulation result analysis}

It can be seen from Figures $6 a, 6 c$, and $6 \mathrm{~d}$ that as the SCD 
increases, the velocity in the pipe decreases rapidly, and a large pressure drop occurs, which is related to the small eddy current and recirculation generated in the pipe. This continuously consumes energy, causing the steam velocity to decrease and poor flow uniformity of the steam in the $\mathrm{SC}^{[24,25]}$. The steam velocity at $10 \mathrm{~mm}$ is the fastest $(2-8 \mathrm{~m} / \mathrm{s})$, and the kinetic energy is also the largest, which is beneficial to the horizontal diffusion of steam in the soil, while the steam velocities at $15 \mathrm{~mm}$ and $20 \mathrm{~mm}$ are lower, $1-5 \mathrm{~m} / \mathrm{s}$ and $1-2 \mathrm{~m} / \mathrm{s}$, respectively.

It can be seen from Figures $6 \mathrm{a}, 6 \mathrm{~d}$, and $6 \mathrm{e}$ that the VHD has little effect on the steam velocity and the amount of steam that can fill each SC. It can be seen from Figure 6 that under the same treatment conditions, the steam flow velocity in the six capillaries does not change much, and the distribution is uniform.

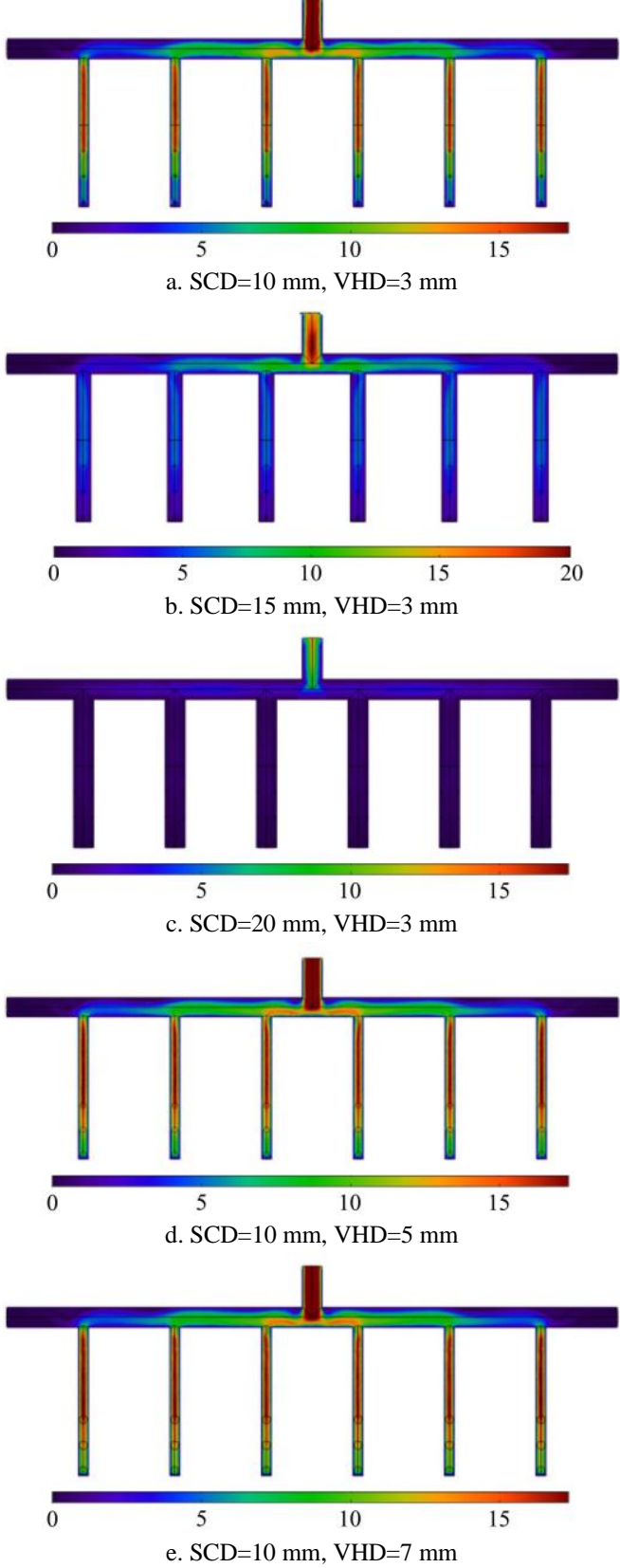

Note: The legend indicates the steam velocity $(\mathrm{m} / \mathrm{s})$ and is added to the bottom of each figure.

Figure 6 Steam velocity contours

\subsection{Effects of capillary pipe diameter on soil temperature and} water content

The results showed that the SCD and the soil type were independent variables, and the ST was tested as the dependent variable. The results are shown in Table 4 , revealing that the SCD and soil type had significant effects on the ST $(p<0.001)$.

Table 4 ANOVA of SCD and soil type

\begin{tabular}{lccccc}
\hline \multicolumn{1}{c}{ Source } & $\begin{array}{c}\text { Type III sum } \\
\text { of squares }\end{array}$ & $\begin{array}{c}\text { Degrees of } \\
\text { freedom }\end{array}$ & $\begin{array}{c}\text { Mean } \\
\text { square }\end{array}$ & $F$-value & $p$-value \\
\hline Correction model & 738.478 & 8 & 92.310 & 24.272 & 0.000 \\
Intercept & 61342.424 & 1 & 61342.424 & 16129.357 & 0.000 \\
SCD & 636.315 & 2 & 318.158 & 83.656 & 0.000 \\
Soil type & 101.437 & 2 & 50.719 & 13.336 & 0.000 \\
SCD $\times$ Soil type & 0.726 & 4 & 0.182 & 0.048 & 0.995 \\
Error & 68.457 & 18 & 3.803 & & \\
Total & 62149.359 & 27 & & & \\
Corrected total & 806.935 & 26 & & & \\
\hline
\end{tabular}

It can be seen from Table 5 that in the clay loam and sandy clay loam, with the increase of the SCD, the ST gradually decreases, and the SCD has an obvious influence on the ST. In the following, the distribution characteristics of the ST and water content are analyzed for different diameters under different soil types.

Under a walking speed of $20 \mathrm{~cm} / \mathrm{min}$ and initial SWC of $25 \%$, from the ST and water content distributions in Figure 7, in the clay loam and silty loam, with the increase in the SCD, the range of the high-temperature region gradually becomes smaller, from elliptical to triangular, and the maximum temperature of the soil with a diameter of $10 \mathrm{~cm}$ is $82^{\circ} \mathrm{C}$. The maximum temperature is found in the horizontal direction at $0-5 \mathrm{~cm}, 14-23 \mathrm{~cm}$ and $32-36 \mathrm{~cm}$ and in the vertical direction between $-10 \mathrm{~cm}$ to $-20 \mathrm{~cm}$. The high water content area is transported from the middle layer $(-10$ to $-15 \mathrm{~cm})$ to the deep layer $(-20 \mathrm{~cm})$. The capillary diameter has an obvious influence on the ST and water content distributions. In the sandy clay loam, with the increase of the SCD, the ST gradually decreases, and the high-temperature region is triangular; the soil high-temperature region and high water content region are concentrated mainly in the lower layers of the soil $(-16$ to $-20 \mathrm{~cm})$. The maximum temperature of the soil with a diameter of $10 \mathrm{~cm}$ is $76^{\circ} \mathrm{C}$, and it is found in the horizontal direction at $0-2.5 \mathrm{~cm}, 15-$ $20 \mathrm{~cm}$ and $33.5-36.0 \mathrm{~cm}$.

From the above steam velocity analysis, the larger the pipe diameter is, the lower the steam velocity. A slower velocity increased the contact time between the fluid micelle and the capillary wall, and the steam and the capillary inner wall had full heat exchange ${ }^{[21]}$. Moreover, the larger the diameter is, the larger the surface area of the outer wall of the SC, which means that more heat will be exchanged with the external environment, accelerating the heat loss from the outer wall of the steam pipe. Thus, most of the vapor has turned into steam and hot water at the bottom of the steam capillary. Therefore, at the same SCS, a larger pipe diameter leads to a higher steam condensate content. As shown by the ST and SWC profiles, the larger the pipe diameter is, the lower the steam velocity. The ST gradually decreases, and the range of high-temperature soil decreases. These test results are consistent with the velocity simulation results. Moreover, as the pipe diameter increased, the volume fraction of the liquid phase of the SC bottom gradually rose, and the high-SWC zone gradually moved downward; these test results are also consistent with the steam condensation simulation results. Additionally, the steam condenses in the SC, and a large amount of latent heat is released into the air from the SC rather than being completely released into the soil to heat the soil, resulting in an ineffective loss of heat and decreased ST. 
Table 5 Soil temperature changes under different treatments

\begin{tabular}{|c|c|c|c|c|c|c|c|c|c|}
\hline \multirow{2}{*}{$\begin{array}{l}\text { Soil type } \\
\mathrm{SCD} / \mathrm{cm}\end{array}$} & \multicolumn{3}{|c|}{ Clay loam (CL) } & \multicolumn{3}{|c|}{ Sandy clay loam (SCL) } & \multicolumn{3}{|c|}{ Silty loam (SL) } \\
\hline & 10 & 15 & 20 & 10 & 15 & 20 & 10 & 15 & 20 \\
\hline Average ST & $55.9 \pm 1.2^{\mathrm{a}}$ & $49.4 \pm 0.75^{\mathrm{b}}$ & $44.3 \pm 0.66^{\mathrm{c}}$ & $51.5 \pm 1.13^{\mathrm{a}}$ & $44.3 \pm 3.18^{\mathrm{b}}$ & $39.6 \pm 2.9^{\mathrm{b}}$ & $54.2 \pm 0.61^{\mathrm{a}}$ & $47.7 \pm 0.5^{\mathrm{b}}$ & $42.1 \pm 0.15^{\mathrm{c}}$ \\
\hline
\end{tabular}

Note: The SCD is treated under the condition that the $\mathrm{VHD}=3 \mathrm{~mm}$; the average ST has expressed as the mean \pm standard deviation; under the same soil type but different $\mathrm{SCD}$ treatments, different letters indicate significant differences at $p<0.05$ level.
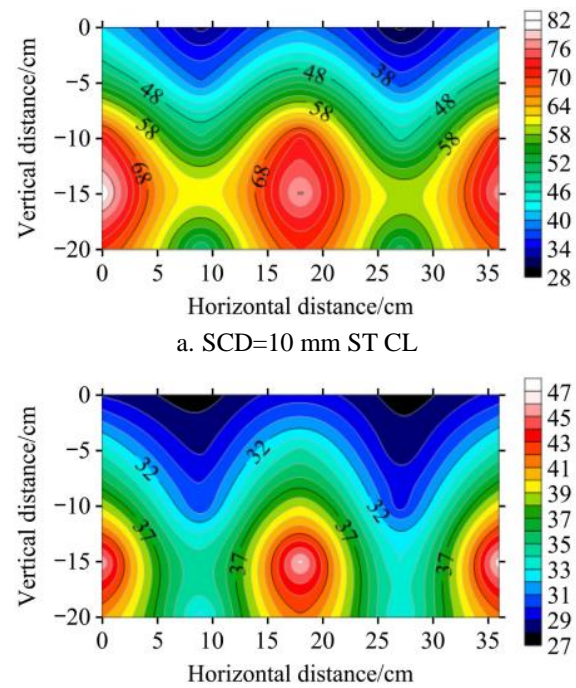

d. $\mathrm{SCD}=10 \mathrm{~mm}$ SWC CL

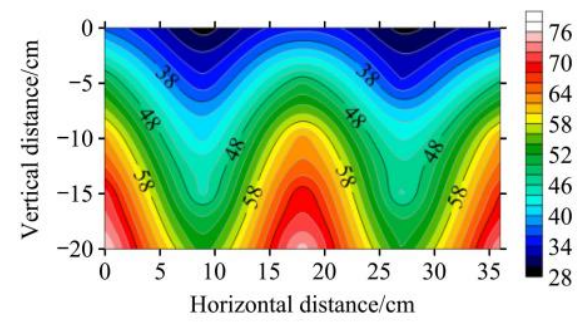

g. $\mathrm{SCD}=10 \mathrm{~mm} \mathrm{ST} \mathrm{SCL}$

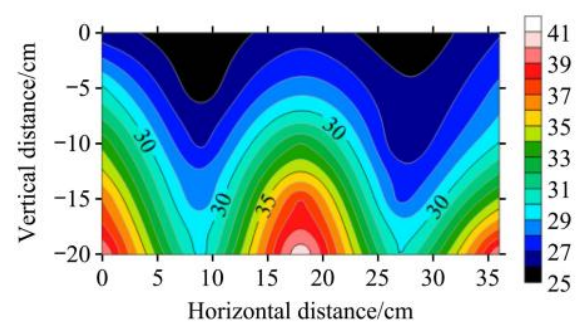

j. SCD=10 mm SWC SCL

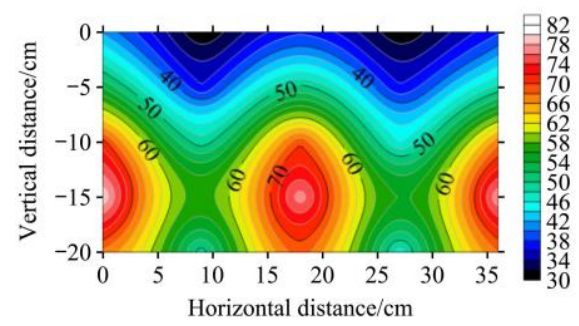

$\mathrm{m} . \mathrm{SCD}=10 \mathrm{~mm}$ ST SL

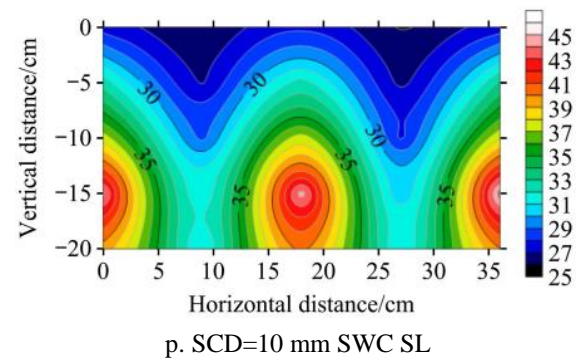

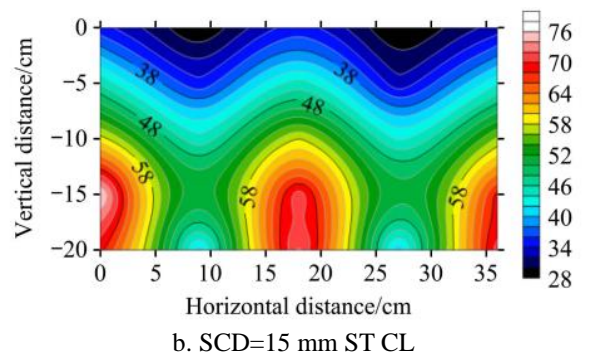

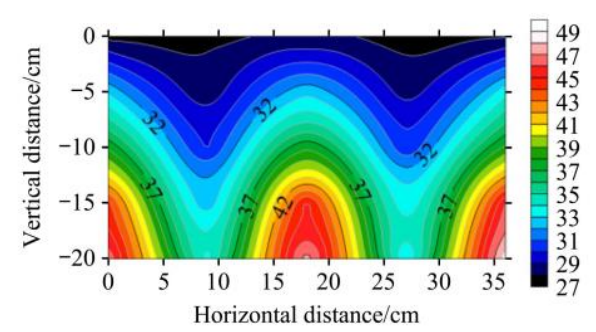

e. $\mathrm{SCD}=15 \mathrm{~mm} \mathrm{SWC} \mathrm{CL}$

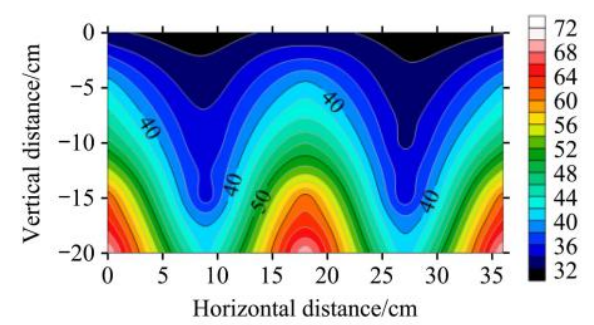

h. SCD $=15 \mathrm{~mm} \mathrm{ST} \mathrm{SCL}$

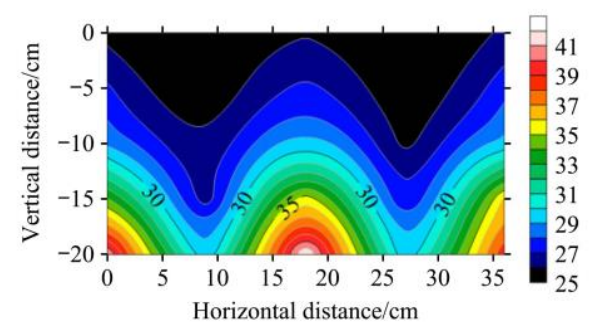

k. SCD $=15 \mathrm{~mm}$ SWC SCL

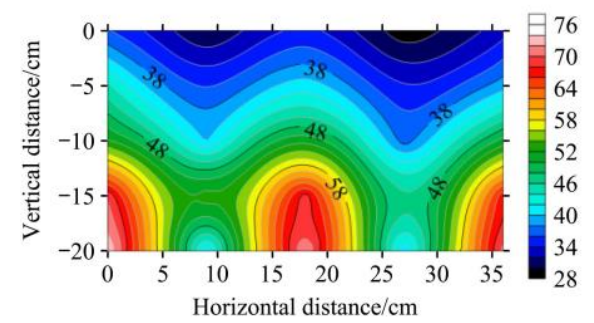

n. SCD $=15 \mathrm{~mm}$ ST SL

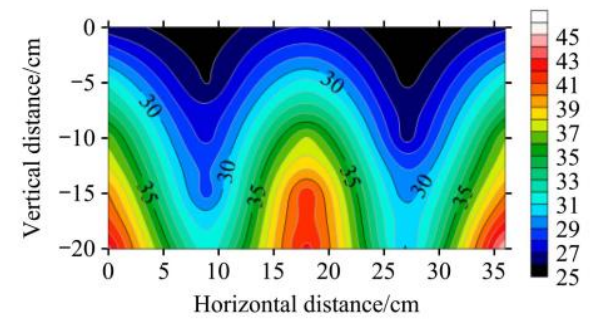

q. $S C D=15 \mathrm{~mm}$ SWC SL
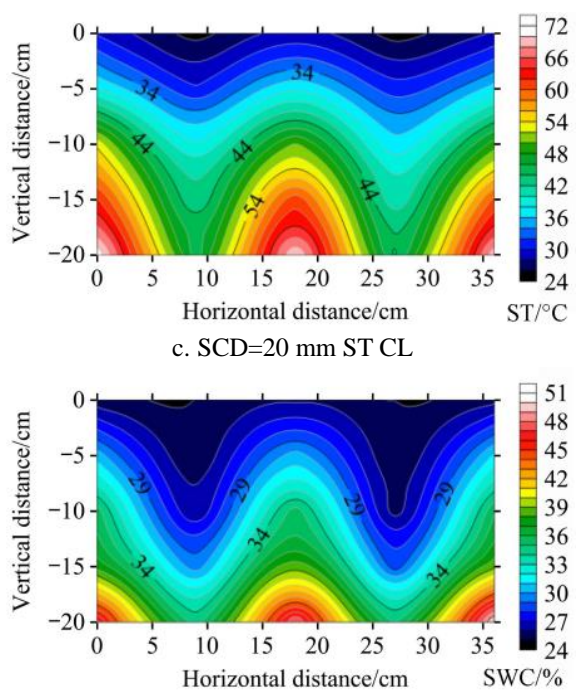

f. SCD=20 mm SWC CL

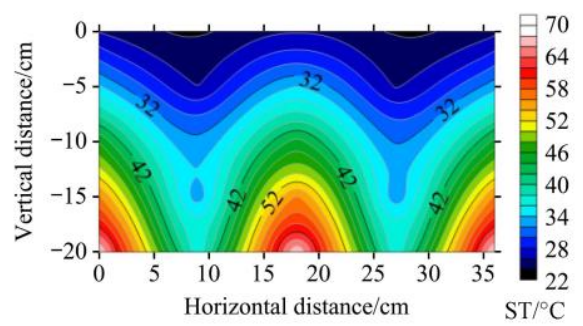

i. $\mathrm{SCD}=20 \mathrm{~mm}$ ST SCL

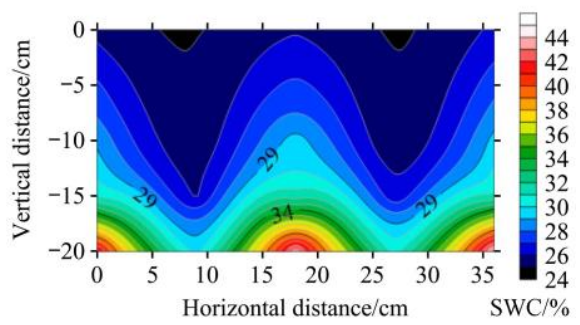

1. $\mathrm{SCD}=20 \mathrm{~mm}$ SWC SCL

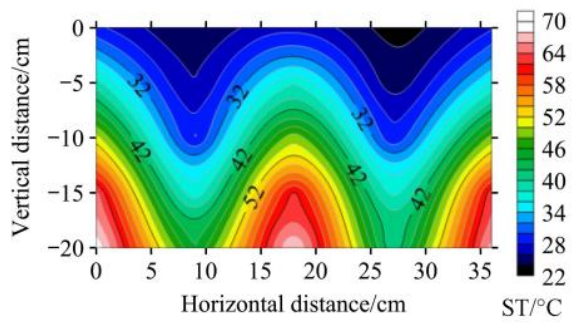

o. $\mathrm{SCD}=20 \mathrm{~mm}$ ST SL

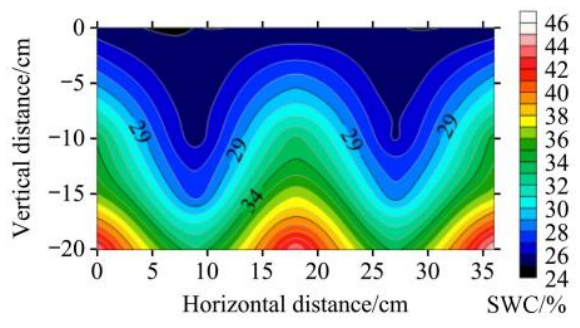

r. SCD=20 mm SWC SL

Figure 7 Soil temperature-water content profiles 
As per the conclusions of previous studies, the factors affecting the ST are also related to the soil type ${ }^{[6]}$. There are three types of soils in this study, namely, clay loam, sandy clay loam, and silt loam. It can be seen from the temperature and water content distribution figures that the clay loam and silt loam soils after disinfection have high ST and water content distribution that are similar and concentrated mainly in the middle layer of the soil, while in the sandy clay loam, the high-temperature and high water content areas are concentrated mainly in the lower layers of the soil. This is because, in the clay loam and silt loam, the contents of silt and low sand are high, and the suction and binding force on the water is largely due to the small spaces between the clay particles and the powder particles, and the heat capacity of the water is greater than that of the air and soil particles ${ }^{[6]}$. Therefore, loam and clay loam have high water holding capacities, and the steam accumulates in the soil, where it does not easily spread out, avoiding the ineffective loss of heat. However, if the sand content is too high, such as in sandy clay loam, the structure will be denser, and the vapor diffusion ability will decrease, which will affect the heating of the soil by steam ${ }^{[6]}$. For experiments in different soils, the effects of different SCDs on the temperatures of different soils are slightly different due to the differences in the soil sand, particle and clay contents, but generally, the larger the pipe diameter, the lower the ST.

\subsection{Effects of soil water content and walking speed on soil temperature}

The results showed that under the $\mathrm{SCD}=10 \mathrm{~mm}$, the walking speed, initial SWC and soil type were independent variables, and the ST was tested as the dependent variable. The results are shown in Table 6 , revealing that the walking speed, soil type and interaction between the walking speed and initial SWC had significant effects on the ST $(p<0.001)$.

As with the saliency table, the interaction of the initial SWC of soil and walking speed has a significant effect on the ST. It can be seen from Table 7 that in the clay loam and sandy clay loam, when the walking speed is $10 \mathrm{~cm} / \mathrm{min}$, the initial soil water content is proportional to the ST; that is, the larger the water content is, the higher the ST after disinfection. When the walking speed is $30 \mathrm{~cm} / \mathrm{min}$, the initial soil water content is inversely proportional to the ST; that is, the lower the water content is, the higher the ST after disinfection.

Table 6 ANOVA of walking speed, initial SWC and soil type

\begin{tabular}{|c|c|c|c|c|c|}
\hline Sources & Type III sum of squares & Degrees of freedom & Mean square & $F$-value & $p$-value \\
\hline Correction model & 1365.103 & 7 & 195.015 & 97.551 & 0.000 \\
\hline Intercept & 70745.951 & 1 & 70745.951 & 35388.821 & 0.000 \\
\hline Walking speed & 1144.462 & 1 & 1144.462 & 572.487 & 0.000 \\
\hline Initial SWC & 4.601 & 1 & 4.601 & 2.301 & 0.149 \\
\hline Soil type & 144.511 & 1 & 144.511 & 72.288 & 0.000 \\
\hline Walking speed $\times$ Soil & 5.580 & 1 & 5.580 & 2.791 & 0.114 \\
\hline SWC $\times$ Soil & 1.057 & 1 & 1.057 & 0.529 & 0.478 \\
\hline Walking speed $\times$ SWC $\times$ Soil & 4.763 & 1 & 4.763 & 2.383 & 0.142 \\
\hline Error & 31.986 & 16 & 1.999 & & \\
\hline Total & 72143.039 & 24 & & & \\
\hline Corrected total & 1397.088 & 23 & & & \\
\hline
\end{tabular}

Table 7 Soil temperature changes under different treatments

\begin{tabular}{|c|c|c|c|c|c|c|c|c|}
\hline Soil type & \multicolumn{4}{|c|}{ Clay loam (CL) } & \multicolumn{4}{|c|}{ Sandy clay loam (SCL) } \\
\hline Walking speed $/ \mathrm{cm} \cdot \mathrm{min}^{-1}$ & \multicolumn{2}{|c|}{10} & \multicolumn{2}{|c|}{30} & \multicolumn{2}{|c|}{10} & \multicolumn{2}{|c|}{30} \\
\hline Initial SWC/\% & 15 & 35 & 15 & 35 & 15 & 35 & 15 & 35 \\
\hline Average ST & $61.5 \pm 1.27^{\mathrm{b}}$ & $66.8 \pm 1.18^{\mathrm{a}}$ & $50.7 \pm 1.2^{\mathrm{d}}$ & $48 \pm 1.21^{\mathrm{e}}$ & $56.9 \pm 1.19^{\mathrm{c}}$ & $59.6 \pm 1.27^{\mathrm{b}}$ & $46.3 \pm 0.95^{\mathrm{ef}}$ & $44.5 \pm 0.8^{\mathrm{f}}$ \\
\hline
\end{tabular}

Note: The SCD was treated under the condition of the vent hole diameter (SCV) of $3 \mathrm{~mm}$; the outlet hole diameter was treated under the condition of pipe diameter of 10 $\mathrm{mm}$; the average ST is expressed as the mean \pm the standard deviation; under the same SCV ( $3 \mathrm{~mm}$ ) but different SCD treatments, different letters indicate significant differences at the $p<0.05$ level; under the same $\mathrm{SCD}=10$ but different $\mathrm{SCV}$ treatments, different letters indicate significant differences at the $p<0.05$ level.

It can be seen from Figure 8 that during the mobile disinfection process, the temperature of the soil surface layer $(0$ to $-3 \mathrm{~cm})$ is lower than that at the deep soil layer $(-10$ to $-20 \mathrm{~cm})$. As the water content distribution shows, the soil surface water content is relatively low. This is because a great part of the steam is lost to the atmosphere through cracks and fissures that are created by the steam capillary being continuously dragged in soil steaming practice ${ }^{[6]}$, causing the ineffective loss of surface heat from the soil.

It can also be seen from the distributions of the various layers of the soil that when the walking speed is low, the initial water content of the soil is proportional to the temperature of each layer of the soil; that is, the larger the water content is, the higher the ST after disinfection. As the Gay study ${ }^{[6]}$, the ST is proportional to SWC. When the walking speed is higher, the initial soil water content is inversely proportional to the temperature of each layer of the soil; that is, the lower the water content is, the higher the ST after disinfection. According to the above analysis, when the walking speed is low, the soil can be sufficiently heated by steam. However, when the walking speed is high, the soil does not have sufficient time to be heated, and because the specific heat capacity of the soil with high water content is also large, the temperature of the soil with high water content is still low after disinfection, while the temperature of the soil with low water content is high.

In the clay, the main high-concentration area of the soil is at a depth of -10 to $-15 \mathrm{~cm}$, and the high-temperature area in the sand is concentrated mainly at the soil layer depth of $-20 \mathrm{~cm}$. As shown in the water content map, in the clay, the middle layer of the soil $(-10$ to $-15 \mathrm{~cm})$ is the main high water content area, while the 
high water content area of the sand is concentrated in the deep layer of the soil $(-20 \mathrm{~cm})$. Under the same treatment, the soil of each layer of clay has higher water content than that of the sand. The results for sand and clay are in full accordance with the study of Gay et al. ${ }^{[6]}$ and due to the high water content gradient and temperature gradient of the clay, the ST rise rate is very fast ${ }^{[6]}$.
In the sand, though, similar to the water content distribution, the sand holding capacity is poor, and the high water content area is concentrated mainly in the deep soil layer, indicating that the steam does not easily diffuse into the soil middle layer. Thus, the high-temperature area is concentrated mainly in the deep soil layer.

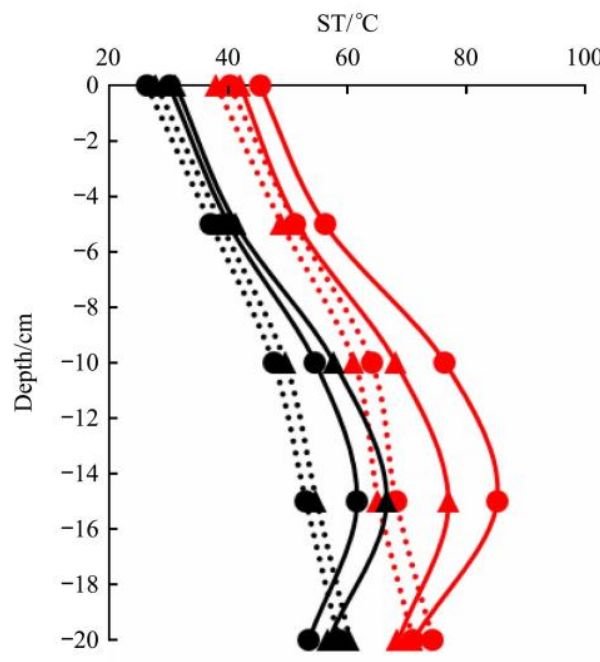

a. Soil temperature

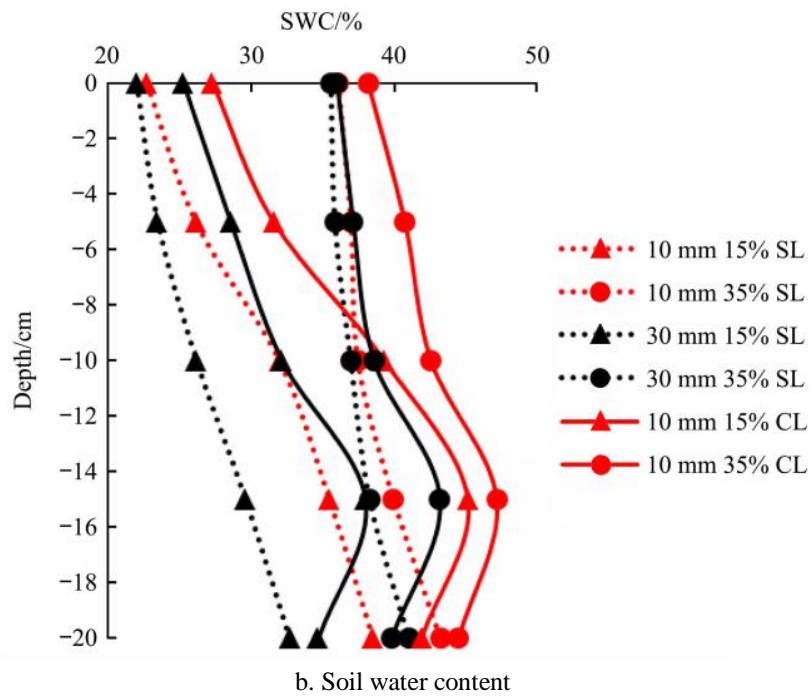

Figure 8 Changes of soil water temperature and moisture content in each treatment

\section{Conclusions}

In this study, numerical simulations of the steam flow field were conducted for different steam capillary diameters (SCD) and vent hole diameters (SCV). Soil steam disinfection tests helped in verifying the accuracy of the simulation model, and the test results were essentially consistent with the simulation results. SCD can affect the steam velocity, which in turn affects the range of the steam thermal effect. The SCD has an effect on the steam velocity and it causes the distance of the horizontal diffusion of the steam in the soil to be small, so that more heat dissipates into the air, lowering the soil temperature (ST) in the clay loam, silt loam, and sandy clay loam.

When the walking speed is low, the initial soil water content is proportional to the ST. However, when the walking speed is high, the law is exactly the opposite; that is, when the soil has large initial water content, the ST is low. Furthermore, when using steam to disinfect the soil, it must be considered that pure sand is not suitable for soil steam disinfection, so the SWC needs to be considered together with the speed. For example, low water content soils can be treated at a high walking speed, while high water content soils require a low walking speed.

\section{Acknowledgements}

The authors acknowledge that this work was financially supported by Jiangsu Province Science and Technology Support Plan Funded Project (Grant No. CX(16)1002) and the Graduate Student Scientific Research Innovation Projects in Jiangsu Province (Grant No. KYCX17_0648).

\section{[References]}

[1] Weiland J E, Littke W R, Browning J E, Edmonds R L, Davis A, Beck B R, et al. Efficacy of reduced rate fumigant alternatives and methyl bromide against soilborne pathogens and weeds in western forest nurseries. Crop Protection, 2016; 85: 57-64.

[2] Cao A C, Zheng J Q, Guo M X, Wang Q X, Li Y. Soil disinfection technology and key points. J. of Vegetables, 2011; 4: 41-44. (in Chinese)

[3] Cao A C, Guo M X, Wang Q X, Li Y, Yan D D. The soil disinfection technology progress. China Vegatables, 2010; 21: 17-22. (in Chinese)

[4] Yang Y T, Hu H, Zhao Q L, Guo D Q, Gao Q S, Guan C S. Research progress of soil physical disinfection equipment. Agricultural Engineering, 2015; 5(S1): 43-48. (in Chinese)

[5] Nishimura A, Asai M, Shibuya T, Kurokawa S, Nakamura H. A steaming method for killing weed seeds produced in the current year under untilled conditions. Crop Protection, 2015; 71: 125-131.

[6] Gay P, Piccarolo P, Aimonino D R, Tortia C. A high efficiency steam soil disinfestation system, part I: physical background and steam supply optimisation. Biosystems Engineering, 2010; 107(2): 74-85.

[7] Peruzzi A, Raffaelli M, Ginanni M, Fontanelli M, Frasconi C. An innovative self-propelled machine for soil disinfection using steam and chemicals in an exothermic reaction. Biosystems Engineering, 2011; 110(4): 434-442.

[8] Khan K S, Müller T, Dyckmans J, Joergensen R G. Development of ergosterol, microbial biomass $\mathrm{C}, \mathrm{N}$, and $\mathrm{P}$ after steaming as a result of sucrose addition, and Sinapis alba cultivation. Biology \& Fertility of Soils, 2010; 46(4): 323-331.

[9] Fennimore S A, Martin F N, Miller T C, Broome J C, Dorn N, Greene I. Evaluation of a mobile steam applicator for soil disinfestation in California strawberry. Hortscience, 2014; 49(12): 1542-1549.

[10] Roux-Michollet D, Dudal Y, Jocteur-Monrozier L, Czarnes S. Steam treatment of surface soil: how does it affect water-soluble organic matter, C mineralization, and bacterial community composition. Biology \& Fertility of Soils, 2010; 46(6): 607-616.

[11] Hoyos E P, Gálvez R B. Influence of grafting and stem disinfection methods on the yield of greenhouse-grown Spanish cucumbers. Acta Horticulturae, 2012; 927: 455-460.

[12] Egli M, Mirabella A, Kägi B, Tomasone R, Colorio G. Influence of steam sterilisation on soil chemical characteristics, trace metals and clay mineralogy. Geoderma, 2006; 131(1-2): 123-142.

[13] Gay P, Piccarolo P, Aimonino D R, Tortia C. A high efficiency steam soil disinfestation system, part II: Design and testing. Biosystems Engineering. Biosystems Engineering, 2010; 107(3): 194-201.

[14] Raffaelli M, Martelloni L, Frasconi C, Fontanelli M, Carlesi S, Peruzzi A. A prototype band-steaming machine: Design and field application. Biosystems Engineering, 2016; 144: 61-71.

[15] Lars E, Martinheide J, Susanne E. Effects of band-steaming on microbial activity and abundance in organic farming soil. Agriculture Ecosystems \& Environment, 2010; 137(3): 223-230. 
[16] Gilbert C, Fennimore S A, Subbarao K, Hanson B, Rainbolt C, Goodhue R E, et al. Systems to disinfest soil with heat for strawberry and flower production. International Research Conference on Methyl Bromide Alternatives and Emissions Reductions, San Diego, California, USA, October, 2009; Paper No. 15.

[17] Lawrence W J C. Soil sterilization. London: Unwin Brothers Limited, 1956.

[18] Philip J R, De Vries D A. Moisture movement in porous materials under temperature gradients. Eos Transactions American Geophysical Union, 1957; 38(2): 222-232.

[19] Chen J L, Lü H X, Shi X, Zhu D L, Wang W E. Numerical simulation and experimental study on hydrodynamic characteristics of T-type pipes. Transactions of the CSAE, 2012; 28(5): 73-77. (in Chinese)

[20] Zhao Y C, Kong D G, Huo J W, Wang Y C, He Y, Zhang Y. Simulation and experiment of air-suction collecting and conveying equipment for small berry. Transactions of the CSAE, 2016; 32(17): 32-39. (in Chinese)
[21] Gao X J, Zhou J H, Lai Q H. Design and experiment of pneumatic cylinder precision seed-metering device for panax notoginseng. Transactions of the CSAE, 2016; 32(2): 20-28. (in Chinese)

[22] Cheng X P, Lu C Y, Meng Z J, Yu J Y. Design and parameter optimization on wheat precision seed meter with combination of pneumatic and type hole. Transactions of the CSAE, 2018; 34(24): 1-9. (in Chinese)

[23] Li X Y, Zhu L, Wang C Y, Wang J H. Optimization of thermally enhanced SVE process for remediation of hydrocarbon contaminated soil by response surface methodology. Chinese Journal of Environmental Engineering, 2018; 12(3): 914-922. (in Chinese)

[24] Yang J, Song H T, Huang Z D, Liu J Wang Z W. Effect of draft tube depth on performance of axial flow fixed-blade turbine. Transactions of the CSAE, 2016; 47(2): 45-50. (in Chinese)

[25] Lin P Y, Hanratty T J. Effect of pipe diameter on flow patterns for air-water flow in horizontal pipes. International Journal of Multiphase Flow, 1987; 13(4): 549-563. 